\title{
Odpowiedzialność zakładu ubezpieczeń za szkody wyrządzone przez agenta ubezpieczeniowego
}

\section{JEL Classification: K15}

Słowa kluczowe: odpowiedzialność na zasadzie ryzyka, agent ubezpieczeniowy, pośrednictwo ubezpieczeniowe, zakład ubezpieczeń, czynności agencyjne

Keywords: insurance company, insurance agent, agency activities, insurance intermediation, liability regime based on the principle of risk

\begin{abstract}
Abstrakt: Tematem niniejszego artykułu została uczyniona odpowiedzialność zakładu ubezpieczeń za szkody wyrządzone przez agenta ubezpieczeniowego w związku z wykonywaniem czynności agencyjnych. Reżim tej odpowiedzialności na zasadzie ryzyka został ukształtowany w Ustawie z dnia 22 maja 2003 r. o pośrednictwie ubezpieczeniowym, w której zdefiniowane zostało również samo pojęcie agenta ubezpieczeniowego oraz wykonywanych przez niego czynności agencyjnych. W dalszej części opracowania prześledzone zostało orzecznictwo Sądu Najwyższego dotyczące wykładni art. 11 ust. 1 wspomnianej ustawy. Omówione zostały podejmowane $\mathrm{w}$ judykaturze próby zdefiniowania różnicy pomiędzy czynnościami wykonywanymi „W związku” a „przy okazji” dokonywania innych czynności. Na zakończenie analizie poddana została kwestia przyczynienia się poszkodowanego do powstania wyrządzonej szkody w tego rodzaju sprawach (art. 362 k.c.).
\end{abstract}

\section{The responsibility of an insurance company for damages caused by an insurance agent}

Abstract: The subject of this article is the responsibility of an insurance company for damages caused by an insurance agent in connection with the performance of agency activities. The Act on Insurance Intermediation of 22 May 2003 lays down a liability regime based on the principle of risk. It also contains the definition of an insurance agent and performed agency activities. In the next part of the article there is analysed the jurisprudence of the Supreme Court concerning the interpretation of article 11 (1) of the abovementioned Act. It discusses an attempt at defining the difference between activities performed "in connection with" and "at the occasion of" other activities. Finally there is analysed an issue of the contribution of the injured party to the occurrence of the damage in this type of cases (article 362 of the Civil Code). 


\section{Wstęp}

Powszechność ubezpieczeń w dzisiejszych czasach uczyniła je nieodzownym elementem porządku prawnego, wymagającym licznych, coraz bardziej szczegółowych, regulacji. Podstawowe przepisy dotyczące umowy ubezpieczenia niezmiennie znajdują się w Kodeksie cywilnym, kształtując ją jako umowę zobowiązaniową, na mocy której jedna ze stron zobowiązuje się do spełnienia konkretnego świadczenia $\mathrm{w}$ razie zajścia określonego $\mathrm{w}$ umowie wypadku, druga zaś — do zapłaty składki. Specyficzną cechą umowy ubezpieczenia jest jej kwalifikowany charakter, tj. jedną z jej stron może być wyłącznie podmiot wskazany przez ustawę, spełniający określone wymagania, nazywany przez ustawodawcę zamiennie „ubezpieczycielem” bądź „zakładem ubezpieczeniowym”.

Ponieważ warunki współczesnego obrotu ubezpieczeniowego wymagają korzystania z pomocy innych osób, jednym z aktów w sposób bardziej szczegółowy normującym kwestię ubezpieczeń jest Ustawa z dnia 22 maja 2003 r. o pośrednictwie ubezpieczeniowym ${ }^{2}$, dostosowana $\mathrm{w}$ swoim obecnym brzmieniu do treści dyrektywy 2002/92/WE z dnia 9 grudnia 2002 r. ${ }^{3}$ Prócz zasad wykonywania pośrednictwa ubezpieczeniowego w zakresie ubezpieczeń gospodarczych określa ona również reguły podejmowania tej działalności oraz definiuje pojęcia agenta oraz brokera ubezpieczeniowego.

Do nawiązania stosunku prawnego pomiędzy zakładem ubezpieczeń a pośrednikiem dochodzi poprzez zawarcie umowy agencyjnej, na podstawie której agent zobowiązuje się, stosownie do art. $758 \S 1$ k.c., w zakresie działalności swego przedsiębiorstwa, do stałego pośredniczenia za wynagrodzeniem przy zawieraniu z klientami umów na rzecz dającego zlecenie przedsiębiorcy albo do zawierania ich w jego imieniu. Do zawierania umów w imieniu zlecającego oraz do odbierania dla niego oświadczeń agent jest natomiast uprawniony tylko wtedy, gdy ma do tego umocowanie (art. $758 \S 2$ k.c.).

Polska praktyka ubezpieczeniowa wyróżnia dwa typy pośredników ubezpieczeniowych. Mimo odmiennej regulacji w dyrektywie, polski prawodawca zdecydował się dać temu wyraz także w przywołanej powyżej ustawie. Pierwszym rodzajem pośredników są agenci ubezpieczeniowi, którzy działają w imieniu i na rzecz konkretnego ubezpieczyciela, będąc stałymi reprezentantami jego interesów. Drugim natomiast - brokerzy działający w imieniu i na rzecz osób poszukujących ochrony ubezpieczeniowej.

1 Z. Gawlik, komentarz do art. $805 \mathrm{KC}$, [w:] Kodeks cywilny. Komentarz, t. 3. Zobowiazania - część szczególna, red. A. Kidyba, Warszawa 2014, LEX nr 8991.

2 Ustawa z dnia 22 maja 2003 r. o pośrednictwie ubezpieczeniowym (Dz.U. z 2014 r. poz. 1450, t.j.; dalej: u.p.u.).

3 Dyrektywa 2002/92/WE Parlamentu Europejskiego i Rady z dnia 9 grudnia 2002 r. w sprawie pośrednictwa ubezpieczeniowego (Dz.U. L 009, 15.01.2003 r.). 


\section{Pojęcie agenta ubezpieczeniowego}

Zgodnie z brzmieniem art. 7 u.p.u. agentem ubezpieczeniowym jest przedsiębiorca wykonujący działalność agencyjną na podstawie umowy agencyjnej zawartej z zakładem ubezpieczeń i wpisany do rejestru agentów ubezpieczeniowych. W konsekwencji agentem ubezpieczeniowym może być nie tylko osoba fizyczna, lecz także każdy podmiot mający formę organizacyjną dopuszczalną przez prawo i posiadający zdolność prawną. Sama usługa pośrednictwa ubezpieczeniowego może być natomiast wykonywana przez podmioty zatrudnione u danego przedsiębiorcy, które spełniają wymagania określone w ustawie ${ }^{4}$. Dlatego też nie w każdym wypadku należy utożsamiać agenta z osobą wykonującą czynności agencyjne. Tożsamość tych pojęć będzie zachodziła jedynie w sytuacji, gdy agentem będzie osoba fizyczna samodzielnie wykonująca wspomniane czynności.

Czynności agencyjne zostały zdefiniowane w art. 4 niniejszej ustawy jako pozyskiwanie klientów, wykonywanie czynności przygotowawczych zmierzających do zawierania umów ubezpieczenia, zawieranie umów ubezpieczenia oraz uczestniczenie w administrowaniu i wykonywaniu umów ubezpieczenia, także w sprawach o odszkodowanie, jak również organizowanie i nadzorowanie czynności agencyjnych. Katalog ten ma charakter zamknięty ${ }^{5}$. Czynnościami faktycznymi jest pozyskiwanie klientów oraz wykonywanie czynności przygotowawczych zmierzających do zawierania umów ubezpieczenia. Do tych czynności należy zaliczyć też bezpośrednią reklamę danego zakładu ubezpieczeń, wyszukiwanie i selekcję klientów, nakłanianie do zawarcia umowy ubezpieczenia, negocjowanie jej warunków, wyjaśnianie poszczególnych klauzul zawartych w tej umowie oraz we wzorcu umowy towarzyszącym danej umowie czy pomoc przy wypełnianiu stosownych formularzy. Zawieranie umów ubezpieczenia jest zaś czynnością prawną, w związku z czym wiąże się ze składaniem oświadczeń woli, do czego jest potrzebne pełnomocnictwo w rozumieniu art. 12 u.p.u. ${ }^{6}$ Czynność prawna dokonana przez agenta ubezpieczeniowego w granicach umocowania pociąga za sobą skutki bezpośrednio dla reprezentowanego ubezpieczyciela.

By móc wykonywać czynności agencyjne, konieczne jest uczynienie zadość wymogom przewidzianym w art. 9 u.p.u. W konsekwencji niekoniecznie muszą być one wykonywane przez danego agenta ubezpieczeniowego osobiście, wystarczające jest ich wykonanie przez osobę fizyczną legitymującą się stosownymi kwalifikacjami. Dlatego też mogą być one podejmowane przez podmioty działa-

4 A. Chróścicki, Pośrednictwo ubezpieczeniowe i finansowe: komentarz, Warszawa 2008, s. 49.

5 Por. wyrok NSA (do 2003.12.31) we Wrocławiu z dnia 24 maja 1991 r., sygn. akt SA/Wr 294/91, LEX nr 9350; odmiennie: P. Bałasz, K. Szaniawski, Ustawa o pośrednictwie ubezpieczeniowym. Komentarz, Kraków 2005, LEX nr 8253.

${ }^{6}$ E. Wieczorek, komentarz do art. 4 ustawy o pośrednictwie ubezpieczeniowym, [w:] Prawo ubezpieczeń gospodarczych. Komentarz, t. 1. Komentarz do przepisów prawnych o funkcjonowaniu rynku ubezpieczeń, red. Z. Brodecki, M. Glicz, M. Serwach, Warszawa 2010, LEX nr 8063. 
jące w imieniu i na rzecz agenta, tj. przez tzw. pośredników agencyjnych. Równocześnie przyjmuje się, że - choćby ze względu na konieczność odbycia szkolenia — osoby te w każdym wypadku będą znane zakładowi ubezpieczeń.

\section{Zasady odpowiedzialności za szkody wyrządzone przez agenta ubezpieczeniowego}

Artykuł 11 u.p.u. wprowadza zasady odpowiedzialności agenta oraz zakładu ubezpieczeń za szkody powstałe w związku z wykonywaniem czynności agencyjnych. Odpowiedzialność ta uzyskuje w ten sposób samodzielną podstawę prawną, niezależną od przepisów Kodeksu cywilnego. Ponadto norma ta wprost wyłącza możliwość stosowania — określającego tzw. winę w wyborze — art. 429 k.c. stanowiącego, że:

Kto powierza wykonanie czynności drugiemu, ten jest odpowiedzialny za szkodę wyrządzoną przez sprawcę przy wykonywaniu powierzonej mu czynności, chyba że nie ponosi winy w wyborze albo że wykonanie czynności powierzył osobie, przedsiębiorstwu lub zakładowi, które w zakresie swej działalności zawodowej trudnią się wykonywaniem takich czynności.

Regulacja ta nie zwalnia przy tym z odpowiedzialności samego agenta. Dlatego też, jeśli poszkodowany będzie w stanie udowodnić winę agenta w wyrządzeniu szkody, będzie miał także możliwość wytoczenia - na podstawie art. 415 k.c. — alternatywnego powództwa bezpośrednio przeciwko agentowi. Na marginesie warto dodać, że ze względu na brzmienie art. 7 u.p.u. możliwość pociągnięcia do odpowiedzialności zakładu na podstawie art. 11 ust. 1 u.p.u. staje się wątpliwa, gdy brakuje konstytutywnego wpisu agenta do rejestru?

Zgodnie z brzmieniem niniejszego artykułu za szkodę wyrządzoną przez agenta ubezpieczeniowego odpowiada zakład ubezpieczeń, na rzecz którego ten pierwszy działa. Wedle Tadeusza Wiśniewskiego dla uznania odpowiedzialności danego zakładu ubezpieczeń nie ma natomiast znaczenia, czy szkoda powstała z powodu działania agenta-pośrednika, czy też agenta-pełnomocnika. W pierwszym wypadku działanie ogranicza się do sensu stricto pośredniczenia przy zawieraniu umowy, tj. stwarza dającemu zlecenie możliwość samodzielnego zawarcia umowy z osobą trzecią. W drugim zaś agent nie tylko działa na rzecz, lecz także w imieniu zakładu, który reprezentuje ${ }^{8}$.

Reguła ta doznaje jednakże pewnego ograniczenia odnośnie do działalności tzw. multiagentów, tj. agentów, którzy wykonują czynności agencyjne na rzecz więcej niż jednego zakładu ubezpieczeń w zakresie tego samego działu ubezpieczeniowego. Odmiennie aniżeli pozostali agenci odpowiadają oni bowiem samodzielnie za szkody powstałe u osób trzecich z tytułu wykonywania wspomnianych

7 Por. T. Wiśniewski, Odpowiedzialność za szkodę wyrządzona przez agentów ubezpieczeniowych, „Przegląd Sądowy” 2004, nr 3, s. 38.

${ }^{8}$ Por. ibidem. 
czynności. Z tego też powodu w art. 11 ust. 3 u.p.u. ustawodawca zdecydował się nałożyć na nich obowiązek posiadania ubezpieczenia od odpowiedzialności cywilnej, którego wykonywanie kontrolowane jest przez Komisję Nadzoru Finansowego. Multiagentowi, który nie dopełni niniejszej powinności, grozi konieczność uiszczenia stosownej opłaty na rzecz Skarbu Państwa (jej wysokość została określona w art. 11 ust. 4 u.p.u.). Zapłata tej swoistej „grzywny” nie powoduje jednakże uchylenia obowiązku zawarcia wspomnianej umowy ubezpieczenia?

Za szkody powstałe w związku z czynnościami wykonywanymi przez agentów wyłącznych odpowiedzialność ponosi zakład ubezpieczeń. Jest to rodzaj gwarancji, który zastępuje w tym wypadku obowiązek ubezpieczenia się od odpowiedzialności cywilnej. Ubezpieczyciel odpowiada za nie osobiście i w sposób nieograniczony, czyli całym swym majątkiem teraźniejszym i przyszłym, stając się jednocześnie zobowiązanym do naprawienia powstałej szkody ${ }^{10}$. Odpowiedzialność ta może mieć zarówno charakter kontraktowy, jak i deliktowy. W pierwszym wypadku szkoda zostaje wyrządzona przez niewykonanie lub nienależyte wykonanie zobowiązania przez dłużnika — zakład ubezpieczeń, co wynika już z samej istoty istniejącego pomiędzy nim a agentem stosunku przedstawicielstwa. Odszkodowanie w tej sytuacji zastępuje bądź uzupełnia zadeklarowane, a niewykonane świadczenie główne. W drugim zaś wypadku szkoda powstaje niezależnie od istniejącego uprzednio między ubezpieczycielem a ubezpieczającym stosunku prawnego, rodząc tym samym nowy, łączący ich stosunek obligacyjny. Komentowany przepis dotyczy właśnie tego rodzaju odpowiedzialności ${ }^{11}$.

Zdanie to podzielił również Sąd Najwyższy, w wyroku z dnia 16 września 2009 r. stwierdzając, że:

$\mathrm{Z}$ treści tego przepisu jednoznacznie wynika, że odpowiedzialność zakładu powstaje z chwilą wystąpienia szkody niezależnie od istniejącego uprzednio między zakładem a ubezpieczającym stosunku prawnego. Inaczej, wystąpienie szkody dopiero rodzi stosunek zobowiązaniowy między zakładem a ubezpieczającym ${ }^{12}$.

Odpowiedzialność odszkodowawcza zakładu ubezpieczeń oparta jest na zasadzie ryzyka. Jej istota sprowadza się do uniezależnienia odpowiedzialności dłużnika od winy i bezprawności. W konsekwencji dla odpowiedzialności ubezpieczyciela nie ma znaczenia, czy zachowanie agenta zawiera znamiona winy. Jak zauważa Sąd Najwyższy w wyroku z dnia 17 kwietnia 2015 r.:

Zdarzenie wywołujące szkodę kreuje stosunek zobowiązaniowy między ubezpieczycielem a ubezpieczonym i odnosi się do odpowiedzialności za działania osób, którymi zakład ubezpieczeń posłużył się. [...] W sferze odpowiedzialności deliktowej zakład ubezpieczeń ponosi ją za osoby,

\footnotetext{
9 A. Chróścicki, op. cit., s. 132.

10 E. Wieczorek, op. cit.

11 Ibidem.

12 Wyrok SN z dnia 16 września 2009 r., sygn. akt II CSK 112/09, LEX nr 530581.
} 
którymi się posłużył na zasadzie ryzyka. Na nim bowiem ciąży ryzyko wyboru właściwych osób, którymi posługuje się dla wykonania pośrednictwa ubezpieczeniowego ${ }^{13}$.

Nie jest to jednakże odpowiedzialność absolutna, gdyż odnoszą się do niej przewidziane w Kodeksie cywilnym okoliczności zwalniające od odpowiedzialności na zasadzie ryzyka, tzw. przesłanki egzoneracyjne ${ }^{14}$. Dla przyjęcia ich istnienia nie jest bowiem konieczne, by zostały wprost określone w danym przepisie. Zdania tego w pełni nie podzielił Sąd Najwyższy w wyroku z 20 listopada 2015 r. ${ }^{15}$, w którym zostały wyróżnione dwa typy odpowiedzialności na zasadzie ryzyka. Zgodnie z pierwszym z nich — surowszym — odpowiedzialność ta oderwana jest zarówno od winy osoby zobowiązanej do naprawienia szkody, jak i od winy, a nawet bezprawnego zachowania podmiotów, za których postępowanie osoba ta odpowiada $^{16}$. W łagodniejszej postaci odpowiedzialność ta pozostaje natomiast oderwana od winy osoby zobowiązanej do naprawienia szkody, jednakże zostaje powiązana $\mathrm{z}$ winą lub bezprawnym zachowaniem innego podmiotu, za którego postępowanie osoba ta odpowiada ${ }^{17}$. Dlatego też w drugim wypadku zbędne staje się określanie przesłanek egzoneracyjnych, gdyż funkcję tę pełni wymóg kwalifikowanego (zawinionego lub bezprawnego) zachowania będącego źródłem szkody. Zgodnie z poglądem zaprezentowanym przez Sąd Najwyższy we wspomnianym wyżej wyroku art. 11 ust. 1 u.p.u. kształtuje odpowiedzialność na zasadzie ryzyka zakładu ubezpieczeń w sposób łagodniejszy, tj. uzależniając jej powstanie od bezprawnego zachowania agenta ${ }^{18}$. Na marginesie należy wspomnieć, że zarówno w doktrynie, jak i orzecznictwie reprezentowany jest również pogląd, w myśl którego do przesłanek odpowiedzialności zakładu ubezpieczeń należy ponadto zaliczyć winę po stronie agenta ${ }^{19}$. Ze względu jednakże na brak w polskim prawie możliwości domniemywania przesłanki winy w wypadku braku jej wyraźnego wskazania w przepisie, wydaje się on nie znajdować uzasadnienia. Nie ma natomiast wątpliwości, że odpowiedzialność zakładu ubezpieczeń na podstawie art. 11 ust. 1 u.p.u. jest tzw. odpowiedzialnością pierwotną, tj. poszkodowany nie ma obowiązku dochodzenia naprawienia szkody w pierwszej kolejności od agenta sprawcy. Może on od razu zwrócić się z roszczeniem do ubezpieczyciela.

W każdym wypadku dla pociągnięcia zakładu ubezpieczeń do odpowiedzialności za szkody powstałe w związku z wykonywaniem czynności agencyjnych przez agentów konieczne jest kumulatywne spełnienie następujących przesłanek:

13 Wyrok SN z dnia 17 kwietnia 2015 r., sygn. akt I CSK 216/14, LEX nr 1665335.

14 Por. wyrok SN z dnia 13 sierpnia 2015 r., sygn. akt I CSK 657/14, Legalis nr 1358785; tak też

T. Wiśniewski, op. cit., s. 41.

15 Wyrok SN z dnia 20 listopada 2015 r., sygn. akt I CSK 919/14, Legalis nr 1522455.

16 Taki typ odpowiedzialności na zasadzie ryzyka pojawia się m.in. w art. 435 k.c.

17 Ma to miejsce m.in. w art. 430 lub 417(1) k.c.

18 Wyrok SN z dnia 20 listopada 2015 r., sygn. akt I CSK 919/14, Legalis nr 1522455.

19 P. Bałasz, K. Szaniawski, op. cit.; wyrok SA w Krakowie z dnia 11 grudnia 2013 r., sygn. akt I ACa 1233/13, LEX nr 1515231. 
powstanie szkody, stwierdzenie winy agenta w zaistniałej szkodzie, istnienie związku przyczynowego między zaistniałą szkodą a czynnościami agencyjnymi, z których wynikła powstała szkoda ${ }^{20}$.

W wyroku z dnia 17 kwietnia 2015 r. Sąd Najwyższy wyjaśnia, że: „Spełnienie warunku szkody następuje wówczas, gdy agent wyrządził ją w związku z wykonywaniem czynności agencyjnych, a nie przy okazji tych czynności"21. Choć konieczność rozróżnienia tych dwóch sytuacji pojawia się na tle prawa cywilnego nie tylko w tym wypadku ${ }^{22}$, brakuje w tej kwestii w literaturze i orzecznictwie spójnego, powszechnie akceptowanego stanowiska. Próba zdefiniowania problemu została podjęta przez Sąd Najwyższy w wyroku z dnia 25 listopada 2005 r. ${ }^{23}$, w którym zwrócono uwagę, że kryterium celu, jakim kierował się zwierzchnik przy powierzaniu wykonania określonej czynności podwładnemu, nie może mieć decydującego znaczenia. Innymi słowy, nieuzasadnione byłoby, gdyby zwierzchnik mógł odpowiadać za szkodę wyrządzoną poszkodowanemu tylko wówczas, gdyby podwładny nie działał zgodnie z zasadniczym celem, jakim kierował się zwierzchnik podczas powierzania mu do wykonania czynności na swój rachunek. Jak zauważył Sąd Najwyższy, wynika to przede wszystkim z tego, że to: „Na powierzającym ciąży [...] ryzyko wyboru właściwych osób do wykonywania powierzanych im czynności na rachunek powierzającego. To ryzyko jest tym szersze, im szerszy jest zespół czynności powierzonych wykonawcy i szerszy potencjalnie krąg osób poszkodowanych" 24 . Każde inne rozumowanie mogłoby bowiem w wielu wypadkach prowadzić do pozbawienia poszkodowanego należnej mu ochrony prawnej.

Dlatego też Sąd Najwyższy w powyższym wyroku zaznacza, że przy określaniu tego, czy szkoda została wyrządzona ,przy wykonywaniu” powierzonych danej osobie czynności, należy brać pod uwage jeszcze inne kryteria pozwalające na stwierdzenie istnienia funkcjonalnego związku pomiędzy powierzeniem i wykonywaniem czynności a powstaniem szkody, takie jak:

- aspekt przedmiotowy funkcjonalnego związku odnośnie do tego, czy sprawca działał w ramach powierzonych mu czynności;

— aspekt podmiotowy, dotyczący kręgu potencjalnych poszkodowanych;

20 A. Chróścicki, op. cit., s. 131.

21 Wyrok SN z dnia 17 kwietnia 2015 r., sygn. akt I CSK 216/14, LEX nr 1665335.

22 Związek tego rodzaju zachodzi również w odniesieniu do odpowiedzialności Skarbu Państwa za szkody wyrządzone przez niezgodne z prawem działanie lub zaniechanie przy wykonywaniu władzy publicznej (art. $417 \S 1$ k.c.), powierzającego za szkody wyrządzone przez drugiego przy wykonywaniu powierzonych mu czynności (art. 429 k.c.) oraz zwierzchnika za szkody wyrządzone przy wykonywaniu przez podwładnego zleconej mu czynności (art. 430 k.c.).

${ }^{23}$ Wyrok SN z dnia 25 listopada 2005 r., sygn. akt V CK 396/05, „Prawo Bankowe” 2006, nr 11, s. 16.

${ }^{24}$ Ibidem. 
— aspekt temporalny podejmowanych czynności (jednorazowe lub wykonywane w dłuższym okresie czasu, powtarzające się);

- miejsce i czas wykonywania czynności (lokal powierzającego, czas pracy lub poza nim);

- posługiwanie się przez podwładnego stosownymi przedmiotami (tzw. rekwizytami) i oznaczeniami przysługującymi powierzającemu (np. jego pieczęciami, pismami firmowymi, zabezpieczeniami);

— podleganie kierownictwu i kontroli zwierzchnika,

— oraz zakres samodzielności co do sposobu wykonywania powierzonej funkcji ${ }^{25}$.

I choć stanowisko to dotyczyło odpowiedzialności podwładnego, tj. art. 430 k.c., może mieć jednak ogólniejsze znaczenie i znaleźć odpowiednie zastosowanie również względem stosunku powiernictwa.

Wątpliwości odnośnie do stosowania — w sposób opisany powyżej — kryterium związku funkcjonalnego wyraził Bartłomiej Ostrzechowski w glosie do wyroku Sądu Najwyższego z dnia 17 kwietnia 2015 r. ${ }^{26}$. Pozostając przeciwnym powrotowi do wąskiej wykładni przesłanki wyrządzenia szkody przy wykonywaniu czynności, autor sugeruje, by przy ustalaniu istnienia związku funkcjonalnego uzasadniającego odpowiedzialność danego podmiotu brać pod uwagę motywy, dla których w ogóle została ona ustanowiona. Jego zdaniem głównym powodem, dla którego ustawodawca zdecydował się na wprowadzenie art. 11 u.p.u., jest zysk zakładu ubezpieczeń odnoszony z posługiwania się agentami ubezpieczeniowymi. W dalszej kolejności zauważa on także, że nie należy abstrahować: „od wspomnianej w art. 18 u.p.u. kwestii nadzoru nad działalnością agenta" 27 . Nie może to jednak prowadzić do objęcia zakresem odpowiedzialności ubezpieczyciela szkód wyrządzonych przez działania agenta w sferze, która nawet teoretycznie nie może podlegać jakiemukolwiek nadzorowi ze strony zakładu. W konsekwencji należy wskazać, że przesłanka funkcjonalnego związku będzie — zdaniem autora spełniona, gdy z samego charakteru czynności agencyjnej powierzonej agentowi wynika istotny wzrost ryzyka wyrządzenia szkody danego rodzaju. B. Ostrzechowski uzasadnia to stwierdzeniem, że: „Skoro bowiem zakład ubezpieczeń decyduje się dla własnej korzyści posłużyć się w swojej działalności agentem, to powinien ponosić ryzyko szkód, na które inne osoby są z tego powodu bardziej narażone" 28 .

Podążając za podglądem wyrażonym w przywołanym wyroku z dnia 25 listopada 2005 r., Sąd Najwyższy w wyroku z dnia 17 kwietnia 2015 r. uznał za szkodę

25 Por. ibidem.

26 B. Ostrzechowski, Odpowiedzialność za szkodę wyrządzona przez agenta ubezpieczeniowego a nierozsądne zachowanie poszkodowanego, „Glosa” 2016, nr 3, s. 72.

27 Ibidem.

28 Ibidem. 
spowodowaną w związku z wykonywaniem czynności agencyjnych szkodę powstałą $\mathrm{z}$ powodu zawarcia $\mathrm{z}$ agentem fałszywej umowy ubezpieczenia na życie, na skutek której doszło do dokonania licznych wpłat, które jednakże nigdy nie trafiły na rachunek ubezpieczyciela. Jako okoliczności przemawiające za pociągnięciem do odpowiedzialności zakładu zostało wskazane, że agent czynności tych dokonywał w swoim biurze, znajdującym się w tym samym budynku co filia pozwanego zakładu, co więcej - na drukach oznaczonych numerem pozwanego ubezpieczyciela. Jako okoliczności łagodzącej Sąd nie potraktował faktu, że agent prowadził własną działalność gospodarczą, tym samym nie podlegając bezpośredniemu kierownictwu ze strony pozwanego zakładu. Jak zostało jednakże zaznaczone, ze względu na istniejącą możliwość sprawowania nadzoru przez ubezpieczyciela nie jest to równoznaczne z uzyskaniem pełnej swobody w zakresie wykonywania powierzonych czynności. W konsekwencji Sąd nie znalazł podstaw do zwolnienia pozwanego zakładu z konieczności naprawienia powstałej szkody ${ }^{29}$.

Podobnie Sąd Najwyższy przyjął w wyroku z dnia 13 sierpnia 2015 r., stwierdzając przy tym, że:

Sformułowanie „w związku z wykonywaniem czynności agencyjnych”, jakim posłużył się ustawodawca w art. 11 ust. 1 u.p.u., przemawia za przyjęciem, że w przepisie tym chodzi o funkcjonalny związek między wyrządzeniem szkody a wykonywaniem czynności agencyjnych. W języku polskim wyraz „związek” oznacza „stosunek rzeczy, zjawisk itp. łączących się ze sobą, wpływających, oddziałujących na siebie; łączność, powiązanie spójność, zależność" (zob. Stownik języka polskiego, Wydawnictwo Naukowe PWN S.A., Warszawa 1995, t. 3, s. 1001). Uzasadnione jest zatem przyjęcie, że w analizowanym przepisie chodzi o stosunek współwystępowania zdarzeń, czyli funkcjonalne powiązanie między wykonywaniem czynności agencyjnych a wyrządzeniem szkody ${ }^{30}$.

Na gruncie stanu faktycznego ze wspomnianego wyroku Sąd Najwyższy wskazał, że za przyjęciem takiego związku przemawia w szczególności powiązanie oferty nazwanej inwestycyjną z uprzednim prawidłowym zawarciem umowy ubezpieczenia oraz jej skierowanie do klientów zakładu ubezpieczeń związanych z nim zawartą wcześniej umową, prowadzenie działalności nazwanej inwestycyjną w siedzibie agencji zakładu ubezpieczeń, posługiwanie się jego firmowymi formularzami oraz pieczęciami i wreszcie wykorzystanie postanowienia $\S 6$ ust. 6 ogólnych warunków ubezpieczenia, w którym była mowa o wpłacaniu składek na rachunek bankowy albo w inny sposób uzgodniony z zakładem ubezpieczeń, dla przekonania o możliwości dokonywania wpłat gotówkowych w siedzibie agencji ${ }^{31}$.

Konieczność zaistnienia obiektywnego związku funkcjonalnego pomiędzy zachowaniem agenta a wyrządzoną w związku z tym szkodą Sąd Najwyższy za-

\footnotetext{
29 Por. wyrok SN z dnia 17 kwietnia 2015 r., sygn. akt I CSK 216/14, LEX nr 1665335.

30 Wyrok SN z dnia 13 sierpnia 2015 r., sygn. akt I CSK 657/14, Legalis nr 1358785.

31 Por. ibidem.
} 
znacza także w wyroku z dnia 30 września 2015 r. Jak zostało zauważone w uzasadnieniu do tegoż orzeczenia:

Odpowiedzialność ubezpieczyciela na podstawie art. 11 ust. 1 u.p.u. ma charakter deliktowy, a jej przesłankami są zachowanie agenta wyrządzające szkodę i pozostające w związku z wykonywaniem czynności agencyjnych. Odpowiedzialność tę uznano za opartą na zasadzie ryzyka i wymagającą wyrządzenia szkody w związku z wykonywaniem czynności agencyjnych (wyrok SN z dnia 16 września 2009 r. II CSK 112/09). Takie sformułowanie i interpretacja dyspozycji normy art. 11 ust. 1 u.p.u. wyraźnie więc wskazuje na odmienność ujęcia przesłanki jego zastosowania od przesłanki przyjętej np. w przepisach art. $429 \mathrm{KC}$ czy w art. $430 \mathrm{KC}$, w których ustawodawca wyraźnie wymaga wyrządzenia szkody tylko „przy wykonywaniu” powierzonych czynności, a nie w związku z ich wykonywaniem. Wyrządzenie szkody w związku z wykonywaniem czynności agencyjnych obejmuje niewątpliwie znacznie szersze spectrum zachowań sprawcy aniżeli wyrządzenie przezeń szkody jedynie przy wykonywaniu powierzonych czynności ${ }^{32}$.

Za niedopuszczalne zostało uznane - dokonane przez pozwanego - uzasadnianie braku istnienia obiektywnego związku funkcjonalnego poprzez wskazywanie na motywy zachowania agenta, tj. działanie we własnym interesie w celu uzyskania korzyści majątkowych w sposób niezgodny z prawem ${ }^{33}$.

Swoiste ukształtowanie reżimu odpowiedzialności ubezpieczyciela za szkody wyrządzone przez jego agenta na gruncie ustawy o pośrednictwie ubezpieczeniowym zasadniczo nie wpływa negatywnie na stosowanie w tych sprawach przepisów księgi zobowiązań Kodeksu cywilnego dotyczących odpowiedzialności, m.in. art. 362 k.c. Zgodnie z jego brzmieniem, jeżeli poszkodowany przyczynił się do powstania lub zwiększenia szkody, obowiązek jej naprawienia ulega odpowiedniemu zmniejszeniu stosownie do okoliczności, a zwłaszcza do stopnia winy obu stron. Przyjmuje się, że o przyczynieniu można mówić dopiero, gdy w rozumieniu przyjętego w art. 361 k.c. związku przyczynowego zachowanie poszkodowanego należy uznać za jedno z ogniw prowadzących do powstania szkody. Poczynienie takich ustaleń przez sąd zobowiązuje go do dokonania oceny stopnia przyczynienia oraz ewentualnej winy poszkodowanego z uwzględnieniem okoliczności konkretnego stanu faktycznego. Warto jednakże zaznaczyć, że przesłanka zawinienia występuje tylko przy odpowiedzialności na zasadzie winy, podczas gdy w wypadku tej na zasadzie ryzyka konieczne jest jedynie dokonanie ustaleń, że zachowanie poszkodowanego charakteryzowało się obiektywnymi nieprawidłowościami, które miały relewantny wpływ na powstanie szkody w określonym wymiarze, tj. zaistniał adekwatny związek przyczynowy.

W konsekwencji, zdaniem Sądu Najwyższego, możliwe jest poczynienie ustaleń, że na gruncie danej sprawy poszkodowany przez agenta przyczynił się do powstania szkody w danym wymiarze poprzez niedochowanie należytej staranności przy dokonywaniu oceny propozycji agenta i bezrefleksyjne poddanie się

\footnotetext{
32 Wyrok SN z dnia 30 września 2015 r., sygn. akt I CSK 702/14, Legalis nr 1341792.

33 Tak też wyrok SN z dnia 14 stycznia 2016 r., sygn. akt I CSK 43/15, Legalis nr 1433107.
} 
przez powoda jego wymaganiom w celu partycypowania w wysokim zysku ${ }^{34}$. Za przyjęciem odmiennej oceny nie może również przemawiać jedynie to, że poszkodowany był konsumentem. Jak bowiem zauważył Sąd Najwyższy w wyroku z dnia 17 kwietnia 2015 r.:

Prawnie ukształtowana ochrona konsumenta dotyczy zasady indywidualnego kształtowania treści i zawierania umów z jego udziałem. Nie może być rozumiana jako przyznanie mu uprzywilejowanej pozycji, która zwalniałaby go z obowiązku staranności przy dokonywaniu oceny treści umowy, którą zamierza zawrzeć ${ }^{35}$.

$\mathrm{Na}$ gruncie stanu faktycznego opisanego we wspomnianym orzeczeniu jako niestaranne i lekkomyślne Sąd ocenił:

Brak należytej rozwagi w ramach współdziałania z agentem pozwanego i niepodjęcie działań mających na celu uzyskanie wiedzy o treści oraz charakterze czynności pozwanego, które miały doprowadzić do osiągnięcia bardzo wysokich zysków, obiektywnej oceny co do rzeczywistej możliwości uzyskania takiego rezultatu. Zaniechanie dążenia do potwierdzenia na piśmie składanych przez agenta propozycji, poprzestanie na zastrzeżeniu o konieczności kontaktowania się bezpośrednio z nim, w obawie o utratę prowizji, oraz wyjaśnienia motywów braku bliższych informacji, które w sposób wyczerpujący były przekazywane podczas procedury wcześniej zawieranej umowy. Częste przekazywanie wysokich kwot, przekraczających jego możliwości, bez należytego potwierdzenia oraz kontroli stanu rachunku, na który miały być wpłacane, niezapoznanie się z otrzymanymi materiałami informacyjnymi dla ustalenia warunków i możliwości dokonywania dopłat, jak też niesprawdzenie zakresu umocowania agenta co do ich bezpośredniego pobierania, a nawet żądania czynienia wpłat, ocenić należało jako lekkomyślne. Niewątpliwie stworzone zostały warunki do pozyskania zaufania powoda i przekonania go, że działania agenta są zgodne $\mathrm{z}$ jego umocowaniem, co jednak nie zwalniało go od powinności obiektywnej oceny możliwości osiągania niespotykanego zysku oraz zainteresowania rzeczywistym przeznaczeniem wpłacanych pieniędzy ${ }^{36}$.

W konsekwencji Sąd Najwyższy doszedł do wniosku, że ustalenia faktyczne dokonane w tej sprawie przez Sąd Apelacyjny jednoznacznie świadczą o niedochowaniu należytej staranności podczas dokonywania oceny propozycji złożonej przez agenta poszkodowanemu oraz jego nieracjonalnemu i bezrefleksyjnemu poddaniu się stawianym wymaganiom w celu partycypowania $\mathrm{w}$ abstrakcyjnie wysokim zysku. Samo określenie zakresu odpowiedzialności odszkodowawczej pozwanego, tj. zakładu ubezpieczeń, uzależnił natomiast od rozważenia wszystkich istotnych okoliczności sprawy oraz przyjęcia, że zysk ten jest znacząco większy niż przyczynienie się powoda.

Zbliżone zdanie Sąd Najwyższy zaprezentował w wyroku z dnia 20 listopada 2015 r., w którym możliwość zakwalifikowania zachowania powódki jako przyczynienia się do szkody w rozumieniu art. 362 k.c. uzależnił od negatywnej odpowiedzi na pytanie, czy postępowanie powódki stanowiło normalne, adekwatne

\footnotetext{
34 Por. ibidem.

35 Wyrok SN z dnia 17 kwietnia 2015 r., sygn. akt I CSK 216/14, LEX nr 1665335.

36 Por. ibidem.
} 
następstwo zachowania agenta pozwanego zakładu ubezpieczeń. W uzasadnieniu zostało zauważone, że:

Wysokich wpłat powódki, jakkolwiek w biurze Towarzystwa, to jednak bezpośrednio do rąk agentki w gotówce, czy to na podstawie samych wniosków o zawarcie umowy ubezpieczenia inwestycyjnego, czy to nawet bez takich wniosków na papierze firmowym, z potwierdzeniem jedynie na zwykłych kartkach papieru, nie można uznać za normalne następstwo czynności podejmowanych przez M.B. jako agentkę strony pozwanej. M.B., mimo iż wykorzystywała swoją funkcję w celach przestępczych, to działała wobec powódki w charakterze agentki ubezpieczeniowej, a do normalnych następstw działania agenta ubezpieczeniowego, tj. takich następstw, jakie zwykle są skutkiem jego funkcjonowania w tej roli, nie jest dokonywanie przez klientów w kontaktach z nim wysokich wpłat gotówkowych, bez umowy, jedynie z potwierdzeniem na firmowym wniosku o zawarcie umowy, czy nawet tylko na zwykłej kartce papieru. [...] Szeroko rozbudowana regulacja prawna pośrednictwa ubezpieczeniowego [...] daje klientom do dyspozycji szereg środków pozwalających ocenić, mówiąc najogólniej, wiarygodność podejmowanych przez nich transakcji. Powódka angażując znaczne kapitały w transakcje $\mathrm{z}$ agentką ubezpieczeniową strony pozwanej, zignorowała te środki ${ }^{37}$.

Ponadto Sąd Najwyższy podkreślił, że ochrona uczestników obrotu prawnego mających niesłusznie zaufanie, że dany stan prawy faktycznie istnieje, jest w naszym systemie prawnym traktowana jako wyjątkowa.

W sposób łagodniejszy Sąd Najwyższy wypowiedział się w wyroku z dnia 13 sierpnia 2015 r., w którym zasadniczo wykluczył możliwość przyczynienia się poszkodowanej do powstania szkody w danym stanie faktycznym, mimo że w okresie przekazywania wpłat była ona równocześnie zatrudniona jako asystentka nieuczciwego agenta. Zdaniem sądu postępowania poszkodowanej nie można było uznać za bezkrytyczne i nieporadne. Przemawia za tym chociażby fakt, że w tym samym okresie agentowi udało się przekonać blisko 100 osób do dokonania podobnych operacji pieniężnych w celu ich fałszywego zainwestowania. Ponadto występujący pomiędzy sprawcą szkody a poszkodowaną stosunek zatrudnienia Sąd potraktował jako okoliczność, która sprzyjała i uzasadniała jej zwiększone zaufanie względem agenta ${ }^{38}$.

Podstaw dla zmniejszenia wysokości powstałej szkody w związku z przyczynieniem się poszkodowanego Sąd Najwyższy nie dopatrzył się również w wyroku z dnia 15 stycznia 2016 r. ${ }^{39}$, w którym z kolei dla uzasadnienia swojego stanowiska odwołał się do treści ogólnych warunków ubezpieczenia, których nieprecyzyjność potraktował na korzyść klienta zakładu ubezpieczeń. W orzeczeniu tym Sąd Najwyższy poczynił jeszcze jedną istotną obserwację, odwołując się do art. 97 k.c. stanowiącego, iż osobę czynną w lokalu przedsiębiorstwa przeznaczonym do obsługiwania publiczności poczytuje się w razie wątpliwości za umocowaną do dokonywania czynności prawnych, które zazwyczaj bywają dokonywane

\footnotetext{
37 Wyrok SN z dnia 20 listopada 2015 r., sygn. akt I CSK 919/14, Legalis nr 1522455.

38 Por. wyrok SN z dnia 13 sierpnia 2015 r., sygn. akt I CSK 657/14, Legalis nr 1358785.

39 Wyrok SN z dnia 15 stycznia 2016 r., sygn. akt I CSK 51/15, Legalis nr 1402788.
} 
z osobami korzystającymi z usług tego przedsiębiorstwa. W konsekwencji należy zauważyć, że Kodeks cywilny opowiada się za zasadą zaufania, a nie podejrzliwości. Uwaga ta jest o tyle istotna w kontekście orzekania o odpowiedzialności zakładu ubezpieczeń, że w wielu tego typu sprawach do nadużyć dochodzi właśnie w standardowym miejscu pracy agenta, w którym zawierane są również zgodne z prawem - umowy ubezpieczenia. Prócz tego ubezpieczyciel ma prawo do sprawowania w takim miejscu nadzoru i tym samym może kontrolować, jaka działalność jest tam przez agenta faktycznie wykonywana.

Podobne stanowisko zajął Sąd Najwyższy w wyroku z dnia 14 stycznia 2016 r. $^{40}$ W rozważanym w sprawie stanie faktycznym poszkodowany zawarł z agentem umowę ubezpieczenia, w ramach której bez ograniczeń mógł wpłacać środki pieniężne w celu inwestycyjnym na rzecz pozwanego zakładu. Tym niemniej ani z treści umowy, ani ogólnych warunków ubezpieczenia nie wynikało, w jaki sposób wpłaty te powinny być dokonywane. W konsekwencji za niedopuszczalne należy przyjąć wyłączenie ad hoc możliwości ich dokonywania wprost do rąk agenta ubezpieczeniowego. Ponadto w omawianej sprawie czynności te były dokonywane w siedzibie pozwanego zakładu ubezpieczeń, na ręce ich znanego i cenionego agenta. Dlatego też, zdaniem Sądu, braku należytej staranności poszkodowanego można by się dopatrywać tu jedynie w niezweryfikowaniu zapewnień agenta w kwestii nieracjonalnie wysokich zysków. To jednakże samo w sobie powoduje co najwyżej przyczynienie się do powstania szkody w stopniu tak nikłym, że niemogącym wpłynąć na wysokość należnego odszkodowania. W żadnym wypadku natomiast, zdaniem Sądu, o przyczynieniu się do szkody nie może przesądzać brak weryfikacji przez poszkodowanego wpływu kwot przekazanych agentowi na dedykowany rachunek. O bezpieczeństwie przekazanych środków pieniężnych agentowi stanowi art. 6a pkt 1 u.p.u., według którego sumy pieniężne przekazane z tytułu umowy ubezpieczenia przez ubezpieczającego pośrednikowi ubezpieczeniowemu uznaje się jako wpłacone zakładowi ubezpieczeń ${ }^{41}$.

Kwestia stosowania art. 362 k.c. przy miarkowaniu odszkodowań należnych od zakładu ubezpieczeń została również poddana analizie w piśmiennictwie - we wspomnianej już glosie do wyroku Sądu Najwyższego z dnia 17 kwietnia 2015 r. Autor podkreśla w niej, że zakład ubezpieczeń na podstawie art. 11 ust. 1 u.p.u. nie odpowiada za czyn własny, a jedynie podmiotu, nad którym sprawuje nadzór. W konsekwencji powstaje pytanie, czy zakres odpowiedzialności sprawcy oraz osoby ponoszącej odpowiedzialność może być różny. I choć odpowiedzialność zakładu ubezpieczeń i jego agenta jest solidarna, a w związku z tym zasadniczo nie jest dopuszczalne miarkowanie odszkodowania względem poszczególnych osób ${ }^{42}$,

40 Wyrok SN z dnia 14 stycznia 2016 r., sygn. akt I CSK 43/15, Legalis nr 1433107.

41 Por. ibidem.

42 Por. wyrok SN z dnia 2 grudnia 1970 r., sygn. akt II CR 542/70, OSNC 1971/9, poz. 153; wyrok SN z dnia 22 września 1986 r., sygn. akt IV CR 279/86, LEX nr 530539. 
to $\mathrm{w}$ piśmiennictwie przyjmuje się, że zróżnicowanie sytuacji prawnej współdłużników solidarnych może dotyczyć wysokości świadczenia. Niemniej w takim wypadku solidarność będzie mogła wystąpić jedynie do wysokości najniższego $\mathrm{z}$ długów ${ }^{43}$. W dalszej kolejności, mając na uwadze, że wystąpienie po stronie sprawcy winy umyślnej — zdaniem wielu autorów — pozwala na odstąpienie od wymogu adekwatności związku z przyczynowego, o którym stanowi art. 361 k.c. i objęcia zakresem odszkodowania także nieadekwatnych następnych jego działania, autor stwierdza, że analogicznie można by postąpić w wypadku art. 362 k.c., jeśli szkoda została wyrządzona umyślnie, a poszkodowany wykazał się jedynie lekkomyślnością lub niedbalstwem ${ }^{44}$. Stosowanie tej zasady należy jednakże — zdaniem B. Ostrzechowskiego - wykluczyć, jeśli w grę wchodzi odpowiedzialność osób trzecich za czyny cudze, tj. m.in. zakładu ubezpieczeń na gruncie art. 11 ust. 1 u.p.u. Odpowiedzialność ubezpieczyciela nie ma bowiem charakteru akcesoryjnego wobec odpowiedzialności jego agenta, w związku z czym wysokość należnych odszkodowań w każdym z wypadków nie musi być jednakowa ${ }^{45}$.

We wspomnianej glosie poruszony został jeszcze jeden aspekt związany ze stosowaniem art. 362 k.c. w związku z art. 11. ust. 1 u.p.u., który pojawił się nie tylko w uzasadnieniu do glosowanego orzeczenia. Autor za niedopuszczalne uznaje porównywanie zaniedbań związanych z postępowaniem poszkodowanych z nieodpowiednim nadzorem sprawowanym przez zakład ubezpieczeń nad swoim agentem. Zwraca uwagę, że odpowiedzialność przewidziana w art. 11 ust. 1 u.p.u. jest odpowiedzialnością za czyn cudzy, co automatycznie uniemożliwia dokonywanie wspomnianego zestawienia. Przyczynienie się poszkodowanego do powstania szkody może być oceniane jedynie w odniesieniu do zachowania samego sprawcy, a nie osoby zobowiązanej do naprawienia szkody na mocy stosownych przepisów. Ewentualne nieprawidłowości w sprawowaniu nadzoru nad agentem, do którego zakład ubezpieczeń jest obowiązany na podstawie art. 18 u.p.u., mogą stanowić jedynie podstawę do przypisania mu „dodatkowej” odpowiedzialności, jednakże już za czyn własny ${ }^{46}$.

Rozważając kwestię odpowiedzialności ubezpieczyciela za szkody wyrządzone przez agenta, Sąd Najwyższy podkreślił również, że przy jej ustalaniu nie można odwoływać się do art. 11 ust. 3 u.p.u. w związku z art. 827 § 1 k.c. oraz w związku z art. 9 ust. 1 i art. 11 ust. 2 ustawy o ubezpieczeniach obowiązkowych, ubezpieczeniowym funduszu gwarancyjnym i polskim biurze ubezpieczy-

43 W. Dubis, [w:] Kodeks cywilny. Komentarz, red. E. Gniewek, P. Machnikowski, Warszawa 2014, s. 669.

${ }^{44}$ Zob. P. Granecki, Zasada bezwzględnej odpowiedzialności za szkodę wyrządzona umyślnie (wedtug kodeksu cywilnego), „Studia Prawnicze” 2000, nr 3-4, s. 85.

45 Por. B. Ostrzechowski, op. cit., s. 76.

46 Por. ibidem. 
cieli komunikacyjnych ${ }^{47}$. Zgodnie $\mathrm{z}$ art. 9 tejże ustawy umowa ubezpieczenia obowiązkowego odpowiedzialności cywilnej obejmuje odpowiedzialność cywilną podmiotu objętego obowiązkiem ubezpieczenia za szkody wyrządzone czynem niedozwolonym oraz wynikłe $\mathrm{z}$ niewykonania lub nienależytego wykonania zobowiązania, o ile nie sprzeciwia się to ustawie lub właściwości (naturze) danego stosunku. Jednakże, jak stanowi art. 9 ust. 2 u.u.o.f.g.p.b.u.k., umowa ubezpieczenia obowiązkowego odpowiedzialności cywilnej, o którym mowa w art. 4 pkt 1 i 2 (tj. ubezpieczenie odpowiedzialności cywilnej posiadaczy pojazdów mechanicznych za szkody powstałe w związku z ruchem tych pojazdów oraz ubezpieczenie odpowiedzialności cywilnej rolników z tytułu posiadania gospodarstwa rolnego) obejmuje także szkody wyrządzone umyślnie lub w wyniku rażącego niedbalstwa ubezpieczającego lub osób, za które ponosi on odpowiedzialność. Argument a contrario uzasadnia więc stanowisko, że odpowiedzialność zakładu ubezpieczeń odpowiadającego na podstawie umowy z tytułu ubezpieczenia obowiązkowego odpowiedzialności cywilnej za szkody spowodowane przez tzw. multiagenta - jako niewymieniona w art. 4 pkt 1 i 2 u.u.o.f.g.p.b.u.k. - nie obejmuje szkód wyrządzonych przez niego jako ubezpieczającego umyślnie lub w wyniku rażącego niedbalstwa.

Za niedopuszczalne należy jednak uznać rozumowanie, zgodnie z którym skoro ubezpieczenie od odpowiedzialności cywilnej nie obejmuje odpowiedzialności za wyrządzone umyślnie szkody przez multiagenta w związku z wykonywaniem czynności agencyjnych, to odmienna wykładnia art. 11 ust. 1 u.p.u. prowadziłaby do nieuzasadnionego zróżnicowania zakresu ochrony udzielanej klientom zakładów ubezpieczeń w zależności od tego, czy korzystali z pośrednictwa agenta działającego na rzecz tylko jednego ubezpieczyciela, czy multiagenta. Jak jednakże zauważa Sąd Najwyższy w wyroku z dnia 15 stycznia 2016 r.:

Tej argumentacji prawnej nie można podzielić. Skarżący pomija bowiem okoliczność, że agent działający na rzecz tylko jednego ubezpieczyciela może dokonać ubezpieczenia dobrowolnego od odpowiedzialności cywilnej za szkody wyrządzone w związku z wykonywaniem czynności agencyjnych. Zgodnie z art. 827 § 1 i $2 \mathrm{KC}$, strony takiego stosunku ubezpieczeniowego mogą ustalić, że ubezpieczyciel ponosi także odpowiedzialność za szkodę wyrządzoną przez takiego agenta umyślnie. Oznacza to, że ustawodawca dopuszcza zróżnicowanie zakresu ubezpieczenia od odpowiedzialności cywilnej agentów ubezpieczeniowych, co podważa samą konstrukcję rozumowania strony pozwanej ${ }^{48}$.

Argumentację tę należy uznać za błędną również dlatego, że prowadziłaby do wniosku, iż to umowa ubezpieczenia od odpowiedzialności cywilnej kształ-

47 Ustawa z dnia 21 listopada 2016 r. o ubezpieczeniach obowiązkowych, ubezpieczeniowym funduszu gwarancyjnym i polskim biurze ubezpieczycieli komunikacyjnych (Dz.U. 2016 r. poz. 2060; dalej: u.u.o.f.g.p.b.u.k.).

48 Wyrok SN z dnia 15 stycznia 2016 r., sygn. akt I CSK 51/15, Legalis nr 1402788; tak też wyrok SN z dnia 10 lutego 2016 r., sygn akt I CSK 85/15, Legalis nr 1415243. 
tuje treść stosunku prawnego, z którego ta odpowiedzialność może wyniknąć. W rzeczywistości określa ona natomiast jedynie zakres tej odpowiedzialności za ubezpieczającego. W konsekwencji to treść stosunku agenta działającego na rzecz tylko jednego ubezpieczyciela łączącego go z tym ubezpieczycielem decyduje o zasadzie odpowiedzialności uregulowanej w art. 11 ust. 1 u.p.u., a nie ewentualna dobrowolna umowa o ubezpieczeniu odpowiedzialności cywilnej agenta. Innymi słowy, ograniczenie odpowiedzialności zakładu ubezpieczeń w wypadku działalności multiagentów nie może być odniesione do sytuacji przewidzianej w art. 11 ust. 1 u.p.u., gdyż dotyczy ono samodzielnej odpowiedzialności odszkodowawczej ubezpieczyciela za jego agenta, a nie ograniczonej odpowiedzialności ponoszonej przez zakład ubezpieczeń na podstawie umowy ubezpieczenia odpowiedzialności cywilnej za szkodę wyrządzoną przez tzw. multiagenta, za którą ten ostatni ponosi odpowiedzialność na podstawie art. 11 ust. 2 u.p.u. ${ }^{49}$

\section{Zakończenie}

Mając na uwadze powyższe, wydaje się, że linia orzecznicza Sądu Najwyższego w kwestii wykładni art. 11 ust. 1 u.p.u. zakłada raczej szeroką aniżeli wąską odpowiedzialność zakładu ubezpieczeń za szkody wyrządzone przez agenta w związku z wykonywaniem czynności agencyjnych. Taki stan rzeczy zdaje się zgodny z dyrektywą 2002/92/WE i czynić zadość jej postanowieniom, który to dokument miał bowiem za zadanie tak ukształtować stan prawny, by chronić należycie naruszane wcześniej wielokrotnie interesy klientów. W konsekwencji słuszne wydaje się objęcie ryzykiem ubezpieczyciela wszelkich szkód pozostających w związku funkcjonalnym z wykonywaniem czynności agencyjnych przez podmiot będący jedynie jego agentem ubezpieczeniowym.

Podsumowując, każdy uszczerbek wynikły dla klienta z czynności agencyjnych w rozumieniu art. 4 ust. 1 u.p.u., podejmowanych przez podmiot mający w świetle art. 7 ust. 1 u.p.u. status agenta ubezpieczeniowego i działający w takim charakterze, powinien być lokowany w sferze ryzyka zakładu ubezpieczeń, na rzecz którego agent działa, i objęty odpowiedzialnością odszkodowawczą tego zakładu na podstawie art. 11 ust. 1 u.p.u. Dotyczy to zatem również szkód spowodowanych czynnościami mieszczącymi się w hipotezie art. 4 ust. 1 u.p.u., ale w konkretnym wypadku niewchodzącymi w zakres umocowania agenta ubezpieczeniowego, choćby nawet nie leżały one ani w interesie ubezpieczyciela, ani w interesie klienta. Na zakres tej odpowiedzialności wpływu zasadniczo nie może

49 Por. ibidem; tak też wyrok SN z dnia 14 stycznia 2016 r., sygn. akt. I CSK 43/15, Legalis nr 1433107. 
mieć także okoliczność, że czyny te posiadają znamiona przestępstwa. Zakład ubezpieczeń przez nadzór sprawowany nad działalnością agenta ma możliwość oddziaływania na sferę objętą jego ryzykiem i tym samym jego skutecznego ograniczania.

\section{Bibliografia}

Bałasz P., Szaniawski K., Ustawa o pośrednictwie ubezpieczeniowym. Komentarz, Kraków 2005, LEX nr 8253.

Chróścicki A., Pośrednictwo ubezpieczeniowe i finansowe: komentarz, Warszawa 2008.

Granecki P., Zasada bezwzględnej odpowiedzialności za szkodę wyrządzona umyślnie (wedtug kodeksu cywilnego), „Studia Prawnicze” 2000, nr 3-4.

Kodeks cywilny. Komentarz, red. E. Gniewek, P. Machnikowski, Warszawa 2014.

Kodeks cywilny. Komentarz, t. 3. Zobowiązania - część szczególna, red. A. Kidyba, Warszawa 2014, LEX nr 8991.

Ostrzechowski B., Odpowiedzialność za szkodę wyrządzona przez agenta ubezpieczeniowego a nierozsądne zachowanie poszkodowanego, „Glosa” 2016, nr 3.

Prawo ubezpieczeń gospodarczych. Komentarz, t. 1. Komentarz do przepisów prawnych o funkcjonowaniu rynku ubezpieczeń, red. Z. Brodecki, M. Glicz, M. Serwach, Warszawa 2010, LEX nr 8063.

Wiśniewski T., Odpowiedzialność za szkodę wyrządzona przez agentów ubezpieczeniowych, „Przegląd Sądowy” 2004, nr 3.

\section{Akty prawne}

Dyrektywa 2002/92/WE Parlamentu Europejskiego i Rady z dnia 9 grudnia 2002 r. w sprawie pośrednictwa ubezpieczeniowego (Dz.U. L 009, 15.01.2003 r.).

Ustawa z dnia 22 maja 2003 r. o pośrednictwie ubezpieczeniowym (Dz.U. z 2014 r. poz. 1450, t.j.).

Ustawa z dnia 21 listopada 2016 r. o ubezpieczeniach obowiązkowych, ubezpieczeniowym funduszu gwarancyjnym i polskim biurze ubezpieczycieli komunikacyjnych (Dz.U. z 2016 r. poz. 2060).

\section{Orzecznictwo}

Wyrok SN z dnia 2 grudnia 1970 r., sygn. akt II CR 542/70, OSNC 1971/9, poz. 153.

Wyrok SN z dnia 22 września 1986 r., sygn. akt IV CR 279/86, LEX nr 530539.

Wyrok NSA (do 2003.12.31) we Wrocławiu z dnia 24 maja 1991 r., sygn. akt SA/Wr 294/91, LEX nr 9350.

Wyrok SN z dnia 25 listopada 2005 r., sygn. akt V CK 396/05, „Prawo Bankowe” 2006, nr 11.

Wyrok SN z dnia 16 września 2009 r., sygn. akt II CSK 112/09, LEX nr 530581.

Wyrok SN z dnia 17 kwietnia 2015 r., sygn. akt I CSK 216/14, LEX nr 1665335.

Wyrok SN z dnia 13 sierpnia 2015 r., sygn. akt I CSK 657/14, Legalis nr 1358785.

Wyrok SN z dnia 20 listopada 2015 r., sygn. akt I CSK 919/14, Legalis nr 1522455.

Wyrok SN z dnia 30 września 2015 r., sygn. akt I CSK 702/14, Legalis nr 1341792.

Wyrok SN z dnia 14 stycznia 2016 r., sygn. akt I CSK 43/15, Legalis nr 1433107.

Wyrok SN z dnia 15 stycznia 2016 r., sygn. akt I CSK 51/15, Legalis nr 1402788.

Wyrok SN z dnia 10 lutego 2016 r., sygn akt I CSK 85/15, Legalis nr 1415243.

Wyrok SA w Krakowie z dnia 11 grudnia 2013 r., sygn. akt I ACa 1233/13, LEX nr 1515231.

Studenckie Prace Prawnicze, Administratywistyczne i Ekonomiczne 21, 2017

(C) for this edition by CNS 


\section{The responsibility of an insurance company for damages caused by an insurance agent}

\section{Summary}

The jurisdiction of the Supreme Court according to paragraph 11 act 1, insurance mediation law assumes wider responsibility of the insurance company for damages done by an insurance agent. This state of affairs seems to fulfill the provisions of the directive 2002/92/EC. It task was to shape legal status to protect clients businesses which previous was frequently violated. This situation seems correct to encumber the insurance company with the risk associated with performing agency activities by an agent. 